\title{
Influence of Meloidogyne incognita race 1 on the development of clones of Coffea canephora, variety “Jequitibá Incaper 8122 ”*
}

\section{Influência de Meloidogyne incognita raça 1 no desenvolvimento de clones de Coffea canephora, variedade "Jequitibá Incaper 8122 "}

\author{
Lilian Katiany Castello Rabello Zinger ${ }^{1}$ (1) (orcid.org/0000-0002-9780-6822) \\ Fernando Domingo Zinger ${ }^{2 *}$ * (D) (orcid.org/0000-0003-3552-8895) \\ Fábio Ramos Alves ${ }^{1}$ (D) (orcid.org/0000-0001-8200-2891) \\ Waldir Cintra de Jesus Junior ${ }^{3}$ (D) (orcid.org/0000-0001-5711-0268) \\ Angelo Oliveira Gonçalves ${ }^{1}$ (D) (orcid.org/0000-0003-3151-4875) \\ Tatiane Paulino da Cruz ${ }^{1}$ (D) (orcid.org/0000-0002-9066-7081) \\ Willian Bucker Moraes ${ }^{1}$ (iD) (orcid.org/0000-0001-7478-7772) \\ Guilherme Resende Camara' ${ }^{1}$ (D) (orcid.org/0000-0001-8181-429X)
}

\begin{abstract}
Root-knot nematode is one of the most important phytosanitary problems for Conilon coffee, as it reduces productivity and is difficult to handle. We aimed at studying the infectivity and damage caused by $M$. incognita race 1 in the “Jequitibá Incaper 8122 " intermediate maturity coffee variety. The experiment was conducted in a greenhouse, in completely randomized design, with five replicates. The clones composing the variety "Jequitibá Incaper 8122 " were inoculated with 2,000 eggs + second-stage juveniles of $M$. incognita race 1 . Uninoculated plants were the control. Evaluations were performed 180 days after inoculation, considering the plant height $(\mathrm{H})$, stem diameter (SD), number of leaves (NOL), leaf area (LA), number of plagiotropic branches (NPB), number of nodes $(\mathrm{NN})$, chlorophyll content (CHLO), shoot dry matter (SDM), root fresh matter (RFM), final population (FNP), and reproduction factor (NRF). The nematode reduced NOL in clones 208 and 209, NRF in clones 201, 203, 207 and 208, NN in clones 203, 207, 208 and 209, CHLO in clones 201, 204, 206, 207 and 209, SDM in clones 201, 203, 204 and 205 and RFM in clones 205 and 207. M. incognita race $1 \mathrm{FNP}$ and NRF were larger in clones 208, 201, 207 and 203. Clone 202 had FNP and NRF equal to zero, being immune to the nematode. Clone 206 presented the lowest NRF value among clones parasitized by $M$. incognita.
\end{abstract}

KEYWORDS: Conilon coffee; root-knot nematode; resistance; damage.

\begin{abstract}
RESUMO: O nematoide-das-galhas é um dos mais importantes problemas fitossanitários para o cafeeiro conilon, por reduzir a produtividade e ser de difícil manejo. Objetivou-se estudar a infectividade e os danos causados por $M$. incognita raça 1 na variedade de café conilon de maturação intermediária “Jequitibá Incaper 8122”. O experimento foi conduzido em casa de vegetação, em DIC, com cinco repetições. Os clones que compóem a variedade "Jequitibá Incaper 8122 " foram inoculados com 2.000 ovos + juvenis de segundo estádio de $M$. incognita raça 1 . Plantas não inoculadas constituíram a testemunha. As avaliaçóes foram realizadas 180 dias após a inoculação, sendo avaliados: altura da planta (ALT), diâmetro do caule (DCA), número de folhas (NFO), área foliar (AFO), número de ramos plagiotrópicos (NRP), número de nós $(\mathrm{NN})$, teor de clorofila (CLO), massa seca da parte aérea (MSA), matéria fresca da raiz (MFR), população final (PFN) e fator de reprodução (FRE). O nematoide reduziu o NFO nos clones 208 e 209, NRP nos clones 201, 203, 207 e 208, NN nos clones 203, 207, 208 e 209, CLO nos clones 201, 204, 206, 207 e 209, MSA nos clones 201, 203, 204 e 205 e MFR nos clones 205 e 207. PFN e FRE de M. incognita raça 1 foram maiores nos clones 208, 201, 207 e 203; o clone 202 teve a PFN e a FRE igual a zero, apresentando-se imune ao nematoide. O clone 206 apresentou o menor valor de FRE entre os clones parasitados por $M$. incognita.
\end{abstract}

PALAVRAS-CHAVE: café Conilon; nematoide-das-galhas; resistência; danos. 


\section{INTRODUCTION}

Brazil is the world's largest producer and exporter of coffee (MAPA, 2017). The state of Espírito Santo is the first in the ranking of Conilon coffee production (Coffea canephora Pierre ex A. Fronier) (CONAB, 2018). Conilon coffee is the main raw material for the industry of soluble coffee and blends. The demand and consumption of these types of industrialized coffee have been increasing worldwide (KALSCHNE et al., 2018).

The Conilon coffee variety "Jequitibá Incaper 8122" consists of nine clones and was developed in the state of Espírito Santo by the Instituto Capixaba de Assistência Técnica e Extensão Rural (Incaper) (DOPES, 2013; FERRÃO et al., 2015). The use of these varieties has helped the state production to increase $300 \%$ in the last 20 years (FERRÃO et al., 2013).

Phytonematodes of the genus Meloidogyne represent a serious threat to coffee plantations throughout Brazil (PAULI et al., 2013; BARROS et al., 2014; CONTARATO et al., 2014; BARROS et al., 2014). The susceptibility of $C$. canephora to Meloidogyne incognita parasitism was confirmed by CARNEIRO et al. (2009).

Considering the worldwide importance of Conilon coffee for the coffee industry and the occurrence of Meloidogyne nematodes in the producing regions, it is extremely important to know the patho-system involving Conilon coffee versus Meloidogyne incognita, especially regarding the behavior of new genetic materials against the nematode.

We aimed to evaluate the infectivity and to quantify the damage caused by $M$. incognita race 1 to the nine intermediate maturity clones of Conilon coffee variety "Jequitibá Incaper 8122”.

\section{MATERIAL AND METHODS}

The experiment was carried out in a greenhouse at a completely randomized design (CRD), with five replicates. The nine clones that compose the variety "Jequitibá Incaper 8122" (clones 201, 202, 203, 204, 205, 206, 207, 208 and 209) were inoculated with 2,000 eggs + juveniles of second stage (J2) of M. incognita race 1. Uninoculated plants constituted the control sampling.

Seedlings of the nine clones of the "Jequitibá Incaper 8122 " variety were originated from an accredited nursery and with proven phytosanitary origin. They were transplanted with five to seven pairs of definitive leaves to 20-L pots containing dystrophic Red-Yellow Latosol; sieved in a $2 \mathrm{~mm}$ sieve and treated with previous solarization for 30 days. Planting fertilization and coverage recommended by NOVAIS et al. (1991) were carried out. Irrigation was performed in such a way that the soil moisture reached $80 \%$ of the field capacity.

The pure inoculum of $M$. incognita race 1 was obtained from coffee roots of clone $\mathrm{V} 2$ of the "Vitória" variety infected by $M$. incognita race 1 , which was kept in a greenhouse. The nematode was previously identified by isoenzyme electrophoresis (CARNEIRO; MAZAFFERA, 2001). The substrate used for coffee cultivation was composed of soil and sand. The soil was manually mixed with sand, in the proportion of $1: 1(\mathrm{~V}: \mathrm{V})$, and sterilized in an autoclave at $120^{\circ} \mathrm{C}$ for 20 minutes. This this procedure was repeated for three consecutive days.

The nematodes were extracted using the technique of HUSSEY; BARKER (1973) modified by BONETI; FERRAZ (1981), and the quantification of the inoculum was performed in a Peters chamber under an optical microscope.

Fifteen days after transplanting, an aqueous suspension containing inoculum was deposited in four holes made in the rhizosphere region of the coffee seedlings and, after inoculation, the holes were covered with washed sterile sand.

Evaluations were carried out 180 days after inoculation. The variables evaluated were: plant height $(\mathrm{H})$, number of leaves (NOL), stem diameter (SD), number of plagiotropic branches (NPB), number of nodes (NN), leaf area (LA), shoot dry matter (SDM), fresh matter of the root system per plant (RFM), final nematode population (FNP), reproduction factor (NRF), and chlorophyll content (CHLO).

To assess the FNP, the root system was carefully washed and weighed on an electronic scale, obtaining the RFM. For the quantification of FNP made up of eggs + J2, the methodology proposed by HUSSEY; BARKER (1973), modified by BONETI; FERRAZ (1981), was used. The NRF was obtained by the quotient of the FNP number by the initial population (Pi) used in the plant inoculation.

Using a millimeter ruler, the length and the greatest width of each leaf were measured in millimeters, and the product between length and width was also calculated. Thus, all leaves of each plant were measured in every evaluation period $\left(\mathrm{t}_{\mathrm{x}}\right)$.

After converting the measurements to leaf area, according to the described procedure, the total LA of each plant was calculated in every evaluation time, obtained by adding the areas of each leaf, according to the equation: $\mathrm{LA}_{\mathrm{tx}}=$ $(\mathrm{F} 1+\mathrm{F} 2+\ldots+\mathrm{Fn})$, in which $\mathrm{LA}_{\mathrm{tx}}$ is the total LA of the plant and F1, F2 ... Fn, the areas of each leaf of the plant at the considered $t_{x}$ time. Subsequently, the values were corrected by the equation proposed by KEMP (1960), HUERTA; ALVIM (1962): $\hat{A} F=0.667 . C . L$, in which ÂF is the estimate of the $\mathrm{LA}\left(\mathrm{cm}^{2}\right)$; $\mathrm{L}$ is the greatest length $(\mathrm{cm})$; and W is the largest width $(\mathrm{cm})$.

For the evaluation of the CHLO, the portable chlorophyll meter SPAD-502 (Minolta Chlorophyll Meter 
SPAD $-502^{\circ}$ ) was used, which, in a non-destructive way, provided the accurate reading of the $\mathrm{CC}\left(\mathrm{ng} / \mathrm{cm}^{2}\right)$. Two measurements were taken in each evaluation (one in each side of the central rib) of each leaf of the same physiological age, using the average between the two for the purpose of analysis.

Data were analyzed using the statistical software "GENES" (CRUZ, 2006) for homogeneity analysis of variance, and the means were compared by the Scott-Knott cluster test at a $5 \%$ probability.

\section{RESULTS}

The nematode reduced NOL in clones 208 and 209, NRP in clones 201, 203, 207 and 208, NN in clones 203, 207, 208 and 209, CHLO in clones 201, 204, 206, 207 and 209, SDM in clones 201, 203, 204 and 205, and RFM in clones 205 and 207 (Table 1).

There was no effect of the nematode on H, SD, and LA. The FNP and, consequently, the NRF of $M$. incognita race 1 were higher, respectively, in clones 208, 201, 207 and 203; clone 202 showed FNP and NRF equal to zero, being immune to the nematode (Table 2).

Clones 206, 204 and 205 showed the lowest NRF value among the clones parasitized by $M$. incognita (Table 2).

Table 2. Final nematode population (FNP) and nematode reproduction factor (NRF) of Meloidogyne incognita race 1 parasitizing coffee clones of the variety "Jequitibá Incaper $8122 ", 180$ days after inoculation.

\begin{tabular}{|ccc|}
\hline Clones & FNP & NRF \\
\hline $201^{1}$ & $4,973,848 \mathrm{~b}^{2}$ & $2,486.92 \mathrm{~b}$ \\
\hline 202 & 0 & 0 \\
\hline 203 & $1,385,790 \mathrm{~d}$ & $692.90 \mathrm{~d}$ \\
\hline 204 & $403,100 \mathrm{e}$ & $201.55 \mathrm{e}$ \\
\hline 205 & $511,050 \mathrm{e}$ & $255.53 \mathrm{e}$ \\
\hline 206 & $127,370 \mathrm{e}$ & $63.69 \mathrm{e}$ \\
\hline 207 & $2,599,808 \mathrm{c}$ & $1,299.90 \mathrm{c}$ \\
\hline 208 & $10,118,700 \mathrm{a}$ & $5,059.35 \mathrm{a}$ \\
\hline 209 & $664,360 \mathrm{e}$ & $332.18 \mathrm{e}$ \\
\hline
\end{tabular}

'Coffee plants inoculated with 2,000 eggs + J2 of M. incognita race 1 . ${ }^{2}$ Means followed by the same lowercase letter in the columns do not differ statistically by the Scott-Knott test $(p>0.05)$.

Table 1. Number of leaves (NOL), plagiotropic branches (NPB), nodes (NN), total chlorophyll content (CHLO), shoot dry matter (SDM) and root fresh matter (RFM) of clones of the variety “Jequitibá Incaper 8122", parasitized or not by Meloidogyne incognita race 1,180 days after inoculation.

\begin{tabular}{|c|c|c|c|c|c|c|}
\hline Clones & NOL & NPB & NN & $\mathrm{CHLO}\left(\mathrm{ng} / \mathrm{cm}^{2}\right)$ & $\operatorname{SDM}(g)$ & RFM (g) \\
\hline $201 n^{1}$ & $75.00 \mathrm{~b}$ & $14.20 \mathrm{~b}$ & $33.00 \mathrm{~b}$ & $6.57 b$ & $43.48 b$ & $226.08 \mathrm{a}$ \\
\hline $201 s^{2}$ & $85.00 \mathrm{~b}$ & $16.40 \mathrm{a}$ & $36.00 \mathrm{~b}$ & $7.91 \mathrm{a}$ & $55.38 \mathrm{a}$ & $249.40 \mathrm{a}$ \\
\hline $202 n$ & $57.20 \mathrm{c}$ & $12.00 \mathrm{~b}$ & $30.60 \mathrm{~b}$ & $7.78 \mathrm{a}$ & $36.33 c$ & $229.64 \mathrm{a}$ \\
\hline $202 \mathrm{~s}$ & $57.00 \mathrm{c}$ & $11.80 \mathrm{~b}$ & $30.80 \mathrm{~b}$ & $7.76 \mathrm{a}$ & $35.90 \mathrm{c}$ & $233.32 \mathrm{a}$ \\
\hline $203 n$ & $80.60 \mathrm{~b}$ & $13.25 b$ & $26.75 b$ & $7.74 \mathrm{a}$ & $41.56 b$ & $255.94 \mathrm{a}$ \\
\hline $203 \mathrm{~s}$ & $84.75 b$ & $15.20 \mathrm{a}$ & $35.40 \mathrm{a}$ & $7.75 a$ & $52.47 \mathrm{a}$ & $242.69 \mathrm{a}$ \\
\hline $204 n$ & $93.60 \mathrm{~b}$ & $15.80 \mathrm{a}$ & $42.40 \mathrm{a}$ & $6.98 b$ & $36.64 \mathrm{c}$ & $201.55 b$ \\
\hline $204 \mathrm{~s}$ & $96.00 \mathrm{~b}$ & $16.20 \mathrm{a}$ & $48.20 \mathrm{a}$ & $7.79 a$ & $48.78 \mathrm{a}$ & $153.78 b$ \\
\hline $205 n$ & $63.00 \mathrm{c}$ & $11.80 \mathrm{~b}$ & $31.40 \mathrm{~b}$ & $7.71 \mathrm{a}$ & $34.54 \mathrm{c}$ & $159.02 b$ \\
\hline $205 \mathrm{~s}$ & $69.20 \mathrm{c}$ & $14.00 \mathrm{~b}$ & $37.40 \mathrm{~b}$ & $7.65 \mathrm{a}$ & $42.03 b$ & $204.42 c$ \\
\hline $206 n$ & $115.80 \mathrm{a}$ & $15.80 \mathrm{a}$ & $42.40 \mathrm{a}$ & $7.09 b$ & $54.53 \mathrm{a}$ & $254.74 \mathrm{a}$ \\
\hline $206 \mathrm{~s}$ & $119.40 \mathrm{a}$ & $16.20 \mathrm{a}$ & $43.20 \mathrm{a}$ & $7.77 \mathrm{a}$ & $58.66 \mathrm{a}$ & $271.54 \mathrm{a}$ \\
\hline $207 n$ & $79.00 \mathrm{~b}$ & $13.40 \mathrm{~b}$ & $36.20 \mathrm{~b}$ & $7.13 b$ & $51.73 \mathrm{a}$ & $212.84 a$ \\
\hline $207 \mathrm{~s}$ & $85.40 \mathrm{~b}$ & $17.40 \mathrm{a}$ & $40.60 \mathrm{a}$ & 8.00 a & $57.66 a$ & $224.98 b$ \\
\hline $208 n$ & $69.80 \mathrm{c}$ & $10.60 \mathrm{~b}$ & $28.40 \mathrm{~b}$ & $7.98 \mathrm{a}$ & $41.58 b$ & $224.86 a$ \\
\hline $208 \mathrm{~s}$ & $90.80 \mathrm{~b}$ & 18.20 a & $38.20 \mathrm{a}$ & $7.99 a$ & $48.42 \mathrm{~b}$ & $248.32 \mathrm{a}$ \\
\hline $209 n$ & $98.00 \mathrm{~b}$ & $11.00 \mathrm{~b}$ & $29.80 \mathrm{~b}$ & $7.15 b$ & $53.56 \mathrm{a}$ & $232.18 \mathrm{a}$ \\
\hline $209 \mathrm{~s}$ & $111.40 \mathrm{a}$ & $13.50 \mathrm{~b}$ & $37.80 \mathrm{a}$ & $7.91 \mathrm{a}$ & $58.83 \mathrm{a}$ & $254.51 \mathrm{a}$ \\
\hline
\end{tabular}

'Coffee plants inoculated with 2,000 eggs + J2 of $M$. incognita race $1 .{ }^{2}$ Uninoculated coffee plants. ${ }^{3}$ Means followed by the same lowercase letter in the column belong to the same group, according to the Scott-Knott grouping criterion, at $5 \%$ probability. 


\section{DISCUSSION}

The clones that had the greatest number of reduced variables (201,202, 207 and 208) were the ones that had the highest FNP and NRF, that is, larger nematode populations resulted in greater damage to plants. These damages occurred due to impaired absorption of water and nutrients in plants infected with $M$. incognita, which consequently affected the vegetative growth characteristics. As the root system is damaged, the growth characteristics of the plant become compromised (VAASTA et al., 1998).

During the infectious process and root colonization by root-knot nematodes, the pathogen demands energy for its own growth and reproduction. For Meloidogyne spp., which modify the cells that will feed them, there is hyperplasia and hypertrophy of the nutrient cells and the nutrient uptake of the plant, demanding carbon from the plant. Hence, and taking into account the spatial division between source and drain, the nematodes assume drain characteristics, that is, there is transport of organic nutrients from the aerial part to a distant location, the roots, which will nourish the nematodes (CARNEIRO; MAZAFFERA, 2001).

Clone 202 was immune to $M$. incognita race 1 , and none of its growth traits were affected. This is extremely relevant information for coffee production in Espírito Santo, as BARROS et al. (2014) identified M. incognita (race 1 and 2), M. Exigua and M. paranaensis in coffee plants grown from north to the south of Espírito Santo. None of the clone 202 variables was reduced, because the plant was immune. It is also noteworthy that there is little information in literature about genetic resistance and damage caused by the main species of Meloidogyne spp. to clones of clonal varieties grown in Espírito Santo. In some studies, such as the one by SERA et al. (2006), Conilon 10-1 and 10-2 were resistant to races 1 and 2 of M. incognita and M. paranaensis.

Some C. canephora clones show resistance and/or tolerance to root-knot nematodes. Their use as rootstocks for the production of seedlings to be used in fields infested by Meloidogyne spp. is reported and indicated as a successful management measure in several Arabica coffee-producing regions in the states of Paraná and São Paulo (LIMA et al., 2010). Thus, this is the importance of clone 202 immunity observed in the present study, i.e. it can be evaluated in future breeding programs as a possible rootstock.

According to WANGAI et al. (2014), one of the main mechanisms of coffee resistance to nematodes is hypersensitivity. The authors evaluated the reaction of ten varieties of coffee $C$. arabica and C. canephora to M. incognita and reported different reactions of the genotypes, from susceptible to resistant, with four genotypes of $C$. canephora showing resistance to the nematode.
The development of coffee varieties that are resistant to Meloidogyne spp. is the most economical and practical option for the sustainable management of these pathogens (MAREDIA et al., 2003; ROSSKOPF et al., 2005). Resistant varieties have a $32 \%$ reduction in damage to their roots (CAMPOS; VILLAIN, 2005; CASTILLO; WINTGENS, 2009). Several studies have demonstrated the resistance of C. canephora var. Robusta to Meloidogyne spp. species (WHITEHEAD, 1998; CAMPOS; VILLAIN, 2005; CASTILLO; WINTGENS, 2009).

Some resistant $C$. canephora hybrids to many species of root-knot nematodes and races of $M$. incognita have also been developed in some countries, such as: Robusta variety T3561X T3751 in El Salvador, Nemaya variety whose ancestors are T3751 and T3561 and Apoatã in Brazil (BERTRAND et al., 2001; CAMPOS; VILLAIN, 2005; CASTILLO; WINTGENS, 2009; CABOS et al., 2010). The Romex variety is currently being used in Mexico, whose clones R34, R37 and R48 have shown tolerance to root-knot nematodes (CASTILLO; WINTGENS, 2009; WINTGENS, 2009).

CARNEIRO et al. (2009) evaluated the resistance of C. canephora clones of the "Vitoria - Incaper 8142" variety to different populations of Meloidogyne spp. They concluded that there are sources of genetic resistance in varieties of the Conilon group to populations of $M$. paranaensis, $M$. exigua and M. incognita. However, there have been no reports on resistance in the clonal variety "Jequitibá Incaper 8122" yet.

The presence of $M$. incognita race 1 reduced CHLO in five of the nine clones (201, 204, 206, 207 and 209). Nutrients essential to the constitution of the chlorophyll molecule have their absorption affected by phytonematode parasitism (GONÇALVES et al., 1995). CC allows evaluating the intensity index of the green color in several plant species (NASCIMENTO JUNIOR, 2012). Pigment loss is a visible indicator of events such as stress or water deficiency in plants. According to ASMUS (2001), phytonematodes may cause water stress in plants to the point of intervening in the CC, which may explain the results of the present research.

Conilon coffee is a diploid, self-sterile plant, allogamous due to gametophytic self-incompatibility (CONAGIN; MENDES, 1961; PARTELLI et al., 2006; COVRE et al., 2013). Therefore, when composing clonal varieties, genotypes must be grouped in a way that they not only bring together the characteristics of interest but also enable the maintenance of a broad genetic base, with greater variability to prevent the harmful process of genetic erosion in the future. To this end, clones of the same variety, despite having a series of agronomic characteristics in common, must be distinct in their genetic makeup, providing greater security and stability to coffee growers who choose them for planting 
(FERRÁO et al., 2004). Based on this information, differences found between the clones of the "Jequitibá" variety regarding characteristics such as NOL, NPB, NN, CHLO, SDM and RFM may have been verified by the genetic differences between the nine clones that compose this variety, and not only by $M$. incognita race 1 parasitism.

Conilon coffee is a plant influenced by the conditions imposed on it at the time of planting and during the conduction of the crop. A variety with high genetic and productive potential may have its development compromised by abiotic and biotic stresses, such as $M$. incognita parasitism. With the increasingly occurrence of nematode parasitism in the main varieties already established in the state of Espírito Santo (BARROS et al., 2014), there is uncertainty as to the future of these new launched clones.
Thus, information such as that generated by this work is of fundamental importance for planning the implantation of Conilon coffee crops of the "Jequitibá Incaper 8122 " variety if the planting site has already shown signs of $M$. incognita race 1 .

This scientific paper demonstrated the importance of studying the infectivity and damage caused in Conilon coffee by $M$. incognita race 1, a destructive nematode disseminated in areas where Conilon coffee is grown in the state of Espírito Santo, as well as in other agricultural areas of the world. With this information, technicians and extension workers will have more subsidies to indicate varieties/ clones of Conilon coffee with levels of resistance to this pathogen at the time of implantation or renovation of coffee plantations.

ACKNOWLED GMENTS: We thank the Nucleus for Scientific and Technological Development in Phytosanitary Management of Pests and Diseases (NUDEMAFI), from the Universidade Federal de Espírito Santo (UFES), for their support in carrying out research work.

FUNDING: This study was funded by the National Council for Scientific and Technological Development - CNPQ. This study was financed in part by the Coordenação de Aperfeiçoamento de Pessoal de Nível Superior - Brasil (CAPES) Finance Code 001.

CONFLICTS OF INTEREST: The authors certify that they have no commercial or associative interest that represents a conflict of interest related to the manuscript.

ETHICAL APPROVAL: Not applicable.

AVAILABILITY OF DATA AND MATERIALS: The datasets generated and/or analyzed during the current study are available from the corresponding author on reasonable request.

AUTHORS' CONTRIBUTIONS: Conceptualization: Zinger, L.K.C.R.; Ramos, F.R.; Jesus Junior, W.C.; Moraes, W. Data curation: Zinger, L.K.C.R.; Ramos, F.R. Formal analysis: Zinger, L.K.C.R.; Ramos, F.R. Methodology: Zinger, L.K.C.R.; Ramos, F.R.; Cruz, T.; Gonçalves, A. Writing - review \& editing: Zinger, F.D.; Zinger, L.K.C.R; Ramos, F.R.

\section{REFERENCES}

ASMUS, G.L. Relações densidade populacional Meloidogyne javanica e Heterodera glycines (Nemata: Tylenchoidea), a área foliar, a fotossíntese e os danos causados a variedades de soja. 2000. Thesis (Doctorate degree in Phytopathology) - Escola Superior de Agricultura Luiz de Queiroz, Universidade de São Paulo, Piracicaba, 2001.https://doi. org/10.1 1606/T.1 1.2019.tde-20191220-142837

BARROS, A.F.; OLIVEIRA, R.D.L.; LIMA, I.M.; COUTINHO, R.R.; FERREIRA, A.O.; COSTA, A. Root-knot nematodes, a growing problem for Conilon coffee in Espírito Santo state, Brazil. Crop Protection, v.55, p.74-79, 2014. https://doi.org/10.1016/j. cropro.2013.10.004
BERTRAND, H.G.; ANZUETO, F.; SARA, J.L. Resistance of Meloidogyne exigua in Coffee arabica accession in Ethiopia. Euphytica, v. 118, n.1, p.1-8, 2001.

BONETI, J.I.S.; FERRAZ, S. Modificações do método de Hussey e Barker para extração de ovos de Meloidogyne exigua em raízes de cafeeiro. Fitopatologia Brasileira, Brasília, v.6, n.3, p.553, 1981.

CABOS, R.Y.N.; SIPES, B.S.; SORAIN, M.; SCHMITT, D.P. Evaluation of coffee genotypes for root knot nematodes resistance. Nematotropica, v.40, 191-202, 2010. 
CAMPOS, V.P.; VILLAIN, L. Nematodes parasites of coffee and cocoa. In: LUC, M.; SIKORA, R.A.; BRIDGE, J. (Eds.). Plant parasitic nematodes in subtropical and tropical agriculture. 2. ed. Egham, UK: CABI Bioscience, 2005. p.529-579.

CARNEIRO, R.M.D.G.; COSTA, S.B.; SOUZA, F.R.; SANTOS, D.F.; ALMEIDA, M.R.A.; SANTOS, M.F.A.; SIQUEIRA, K.M.S.; TIGANO, M.S.; FONSECA, A.F.A. Reação de cafeeiros 'conilon' a diferentes populações de Meloidogyne spp. In: SIMPÓSIO DE PESQUISA DOS CAFÉS DO BRASIL, 6., 2009. Vitória, 2009.

CARNEIRO, R.G.; MAZAFFERA, P. Relação fonte-dreno e absorção e transporte de minerais em plantas infectadas por nematoides. In: SILVA, J.F.V. Relações parasito-hospedeiro nas meloidoginoses da soja. Londrina: Embrapa Soja, 2001. p.630-693.

CASTILLO, G.; WINTGENS, J.N. Nematodes in coffee. In: WINTGENS, J.N. Coffee: growing, processing, sustainable production. A guidebook for growers, processors, traders and researchers. 2. ed. 2009. p.478-494. https://doi.org/10.1002/9783527619627.ch17

COMPANHIA NACIONAL DE ABASTECIMENTO (CONAB). Safra 2018 - Primeiro levantamento, v.5, n.1, 72p, 2018. Available from: https://www.conab.gov.br/info-agro/safras/ graos/boletim-da-safra-de-graos/item/download/20861_ fb79e3ca2b3 184543c580cd4a4aa402b. Access on: Jan. 202019.

CONAGIN, C.H.T.M.; MENDES, A.J.T. Pesquisas citológicas e genéticas em três espécies de Coffea: autoincompatibilidade em Coffea canephora. Bragantia, v.20, n. único, p.788-804, 1961. http://dx.doi.org/10.1590/S0006-87051961000100034

CONTARATO, C.; TOMAZ, M.A.; ALVES, F.R.; SOBREIRA, F.M.; JESUS JUNIOR, W.C; RABELLO, L.K.C.; FERRÃO, M.A.G.; FERRÃO, R.G. Reaction of variedade coffee 'Vitória INCAPER 8142' of conillon to parasitism of Meloidogyne exigua. Idesia, v.32, n. 1, p.93-97, 2014. https://doi.org/10.4067/SO718-34292014000100011

COVRE, A.M.; PARTELLI, F.L.; MAURI, A.L.; DIAS, M.A. Crescimento e desenvolvimento inicial de genótipos de café Conilon. Revista Agro@mbiente On-line, v.7, n.2, p.193-202, 2013. https://doi. org/10.18227/1982-8470ragro.v7i2.944

CRUZ, C.D. Programa GENES. Viçosa: UFV, 2006. 382p.

DIÁRIO OFICIAL DOS PODERES DO ESTADO (DOPES). Espírito Santo lança novas variedades clonais de café Conilon. Vitória, Espírito Santo, segunda-feira, 17 jun. 2013 . Available from: https://www.folhavitoria.com.br/geral/blogs/ midiaemercado/2013/07/04/cafe-conilon-em-novasvariedades/. Access on: Sep. 202014.

FERRÃO, R.G.; FONSECA, A.F.A.; FERRÃO, M.A.G.; DE MUNER, L.H.; VERDIN FILHO, A.C.; VOLPI, P.S.; MARQUES, E.M.G.; ZUCATELI, F. Café conilon: técnicas de produção com variedades melhoradas. Vitória: Incaper, 2004. 60p. (Incaper: Circular Técnica, 03 - I).

FERRÃO, R.G.; FERRÃO, M.A.G.; FONSECA, A.F.A.; VERDIN FILHO, A.C.; LANI, J.A.; TÓFFANO, J.L.; TRAGINO, P.H.; BRAVIM, A.J.B.; MORELI, A. P. Jequitibá Incaper 8122 - Nova variedade clonal de café conilon de maturação intermediária para o Espírito Santo. Vitória: INCAPER, 2013.
FERRÃO, R.G.; FERRÃO, M.A.G.; FONSECA, A.F.A.; VOLPI, P.S.; VERDIN FILHO, A.C.; MAURI, A.; LANI, J.A. 'Diamante ES 8112 ', 'ES 8122 - Jequitibá' and 'Centenária ES 8132: new clonal varieties of Coffea canephora, conilon variety with high beverage quality. In: SIMPÓSIO DE PESQUISA DOS CAFÉS DO BRASIL, 9., 2015, Curitiba. Consórcio pesquisa café: oportunidades e novos desafios. Brasília, DF: Embrapa Café, 2015.

GONÇALVES, W.; MAZZAFERA, P.; FERRAZ, L. C.C.B.; SILVAROLLA, M.B.; LIMA, M.M.A. Biochemical basis of coffee tree resistance to Meloidogyne incognita. Plantations, Recherche, Developpement, v.2, n. 1, p.54-58, 1995.

HUERTA, S.A.; ALVIM, P.T. Índice de área foliar y su influencia en la capacidad fotosintética del cafeto. Cenicafe, Caldas, v.13, n.2, p.75-84, 1962.

HUSSEY, R.S.; BARKER, K.R. A comparison of methods of collecting inocula of Meloidogyne spp., including a new technique. Plant Disease Reporter, v.57, p.1025-1028, 1973.

KALSCHNE, D.L.; VIEGAS, M.C.; DE CONTI, A.J; CORSO, M.P.; BENASSI, M.T. Steam pressure treatment of defective Coffea canephora beans improves the volatile profile and sensory acceptance of roasted coffee blends. Food Research International, v.105, n.3, p.393402, 2018. https://doi.org/10.1016/j.foodres.2017.11.017

KEMP, C.D. Methods of estimating the leaf area of grasses from linear measurements. Annals of Botany, Oxford, v.24, n.4, p.491-499, 1960. https://doi.org/10.1093/oxfordjournals.aob.a083723

LIMA, I. M.; COSTA, H.; VENTURA, J. A. Aumenta incidência de nematoide no cafeeiro. Revista Campo e Negócio, Uberlândia, maio, p.82-83, 2010.

MINISTÉRIO DA AGRICULTURA, PECUÁRIA E ABASTECIMENTO (MAPA). Projeções do agronegócio Brasil 2016/17 a 2026/27. Brasília: MAPA, 2017.

MAREDIA, K.M.; DAKON, D.; MOTA SANCHEZ, D. Integrated pest management in the global arena. Wallingford, UK: CABI Publishing, 2003.

NASCIMENTO JUNIOR, V.C. Aplicação de 1-Metilciclopropeno em soja sob déficit hídrico e seus reflexos na fixação biológica do nitrogênio. 72f. 2012. Dissertation (Master degree in Agronomy)Centro de Ciências Agrárias, Universidade Estadual de Londrina, Londrina, 2012.

NOVAIS, R.F.; NEVES, J.C.L.; BARROS, N.F. Ensaio em ambiente controlado. In: OLIVEIRA, A. J. de; GARRIDO, W.E.; ARAUJO, J.D.; LOURENÇO S. Métodos de pesquisa em ambiente controlado. Brasília: Embrapa-SEA, 1991.

PAULI, B.; SALGADO, S.M.L; BOTELHO, T.T.; SOUZA, S.R.; TASSONE, G.A.; SOUZA, J.E.N.; LIMA, I.M. Comportamento inicial de clones de conilon "vitória Incaper 8142 " em área infestada por Meloidogyne paranaensis no sudoeste de Minas Gerais. In: SIMPÓSIO DE PESQUISA DOS CAFÉS DO BRASIL, 8., Salvador, Bahia, 2013. Anais... Salvador: Consórcio Pesquisa Café, 2013.

PARTELLI, F.L.; VIEIRA, H.D.; DETMANN, E.; CAMPOSTRINI, E. Estimativa da área foliar do cafeeiro a partir do comprimento da folha. Revista Ceres, v.53, n.306, p.204-210, 2006. 
ROSSKOPF, E.N.; CHELLENI, N.; KOKALIS, B.; CHURCH, G.T. Alternatives to methyl Bromide: A Florida perspective. Crop Protection Journal, v.8, n.3, p.56-80, 2005. https://doi. org/10.1094/APSnetFeature/2005-0605

SERA, G.H.; SERA, T.; AZEVEDO, J.A.D.; MATA, J.S.D.; RIBEIROFILHO, C.; DOI, D.S.; ITO, D.S.; FONSECA, I.C.; FONSECA, I.C.D.B. Porta-enxertos de café robusta resistentes aos nematóides Meloidogyne paranaensis e $M$. incognita raças 1 e 2 . Semina: Ciências Agrárias, Londrina, v.27, n.2, p.171-184, 2006. https:// doi.org/10.5433/1679-0359.2006v27n2p 171

VAASTA, P.; CASWELL-CHENB, E.P.; ZASOSKI, R.J. Effects of two endoparasitic nematodes (Pratylenchus coffeae and Meloidogyne konaensis) on ammonium and nitrate uptake by Arabica coffee (Coffea arabica L.). Applied Soil Ecology, v.10, n.1-2, p.171-178, 1998. https://doi.org/10.1016/ S0929-1393(98)00037-7

WANGAI, K.J.; NZESYA, M.J.; MAINA, M.W.; PETER, W.M.; ELIJAH, G.K. Reaction of selected coffee germplasm to root-knot nematodes in Kenya. Journal of Natural Sciences Research, v.4, n.3, p.68-75, 2014.

WHITEHEAD, A.G. Plant Nematode Control. Oxon, UK; New York, NY, USA: CAB International, 1998.

WINTGENS, J.N. Coffee: growing, processing, sustainable production. A Guidebook for growers, processors, traders and researchers. $2^{\text {nd }}$ rev. ed. Weinheim, WILEY-VCH Verlag GmbH \& Co. KGaA, 2009. https://doi.org/10.1002/9783527619627 